\title{
Аналіз та оцінка впливу воєнно-економічних факторів на стан розвитку збройних сил України та рівень їі воєнно- економічної безпеки
}

\author{
Олег Семененко * 1 А; Ігор Воронченко ${ }^{2}$ В; Iгор Москаленко 3 C; \\ Сергій Пономаренко ${ }^{4}$; ; Сергій Саєнко ${ }^{5}$; ; Ірина Борисенко 6 А \\ А Центральний науково-дослідний інститут Збройних Сил України, пр-кт Повітрофлотський 28, м. Київ, 03049, Україна \\ в Міністерство оборони України, пр-кт Повітрофлотський 6, м. Київ, 03168, Україна \\ с Національний університет оборони України імені Івана Черняховського, пр-кт Повітрофлотський 28, м. Київ, 03049, Україна
}

Received: June 10, 2021 | Revised: June 19, 2021 | Accepted: June 30, 2021

DOI: $10.33445 /$ sds.2021.11.3.23

\begin{abstract}
Анотація
Отримати найбільш достовірний кінцевий результат щодо майбутнього обрису Збройних Сил України під час оборонного планування можливо тільки за умов повного врахування впливу різноманітних факторів на самі Збройні Сили, як на окрему систему державного рівня, так і на процес їх будівництва та розвитку за визначений планований період. У статті авторами розкрито сутність зовнішніх та внутрішніх економічних факторів, які безпосередньо впливають на стан будівництва та розвитку Збройних Сил України та рівень іï воєнно-економічної безпеки. У статті методом експертного опитування за наявною статистичною інформацією проведено оцінювання рівня впливу основних воєнноекономічних факторів на розвиток Збройних Сил України. Авторами також визначено порядок взаємозв'язку між економічними факторами та їх можливим впливом на шляхи і напрями розвитку 3бройних Сил України за різними рівнями ієрархії процесу оборонного планування. У статті запропоновано для забезпечення гнучкості процесу оборонного планування розглядати впливи економічних факторів з урахуванням їх можливих змін і невизначеностей та відповідно до них формувати гнучкі вимоги до можливого кінцевого очікуваного результату особливо під час середньострокового та довгострокового оборонного планування. Основним напрямом подальших досліджень за визначеною у статті тематикою може бути формування системи показників, які характеризують економічні фактори та розкривають сутність їх впливу, з подальшим обґрунтуванням їх взаємозв'язку, практичної взаємозалежності з цільовими показниками програм розвитку Збройних Сил України та показниками рівня воєнно-економічної безпеки держави.
\end{abstract}

Ключові слова: безпека, ресурси, економіка, аналіз.

\section{Постановка проблеми}

Сучасні вимоги щодо впровадження в практику оборонного планування України принципів та методології планування на основі спроможностей військ (сил), вимагають сьогодні більш детального вивчення перспектив розвитку зовнішнього

\begin{abstract}
середовища особливо щодо тенденцій у змінах: політичних, соціальних, економічних, технологічних тощо, 3 метою формування переліку необхідних спроможностей Збройних Сил (3С) України та оборонної сфери держави в цілому, які будуть
\end{abstract}

\footnotetext{
1 *Corresponding author: д. військ. н., професор., начальник відділу, e-mail: aosemenenko@ukr.net, ORCID: 0000-0001-6477-3414

2 Головний інспектор, e-mail: aosemenenko@ukr.net, ORCID: 000-0001-6074-2995

3 Здобувач наукового ступеню, e-mail: aosemenenko@ukr.net, ORCID: 0000-0002-7822-6419

4 Здобувач наукового ступеню, e-mail: aosemenenko@ukr.net, ORCID: 0000-0002-8939-3415

${ }^{5}$ Здобувач наукового ступеню, e-mail: aosemenenko@ukr.net, ORCID: 0000-0002-6713-1545

${ }^{6}$ e-mail: aosemenenko@ukr.net, ORCID: 0000-0003-1640-853X
} 
адекватними визначеним ймовірним загрозам державі та дозволять забезпечити необхідний рівень ії воєнної та економічної безпеки. Вірно сформований перелік спроможностей ЗС України, в свою чергу, дозволить спланувати відповідні заходи як з набуття цих спроможностей, так і знайти дієві відповіді на виклики, які можуть виникнути у разі зміни зовнішньої та внутрішньої воєннополітичної та економічної обстановки навколо держави та в середині неї [1]-[3], [9].

\section{Аналіз останніх досліджень та публікацій}

Аналіз стану розвитку збройних сил інших країн світу та нових вимог до планування розвитку ЗС України показує, що сьогодні існує потреба в якісних змінах в системі оборонного планування України, особливо щодо питання достовірності та визначеності із кінцевим очікуваним результатом практичної реалізації намічених планів під час їх формування [1]-[6]. Отримати найбільш достовірний кінцевий результат щодо майбутнього обрису зС України під час процесу планування можливо тільки за умов повного врахування впливу різноманітних факторів на самі 3С, як на окрему систему державного рівня, так і на процес їх будівництва та розвитку за будь-який визначений період часу. Фактори (це від лат. factor - діючий, впливаючий) - це існуючі матеріальні та духовні можливості, які впливають на процес будівництва Збройних Сил [4].

Вірне урахування впливів різних факторів під час формування планів та програм розвитку 3 С України, а також достовірне визначення в них кінцевих очікуваних результатів на планований період $\epsilon$ запорукою правильного уявлення керівництвом держави щодо необхідного рівня її воєнно-економічної безпеки в цей період. Сьогодні одним із найпоширених визначень щодо воєнно-економічної безпеки (ВЕБ) держави $€$ те, що її визначають як спроможність держави реалізувати національні інтереси в воєнно-економічній сфері на основі узгодження воєнних потреб та економічного потенціалу держави, насамперед за рахунок збалансування ресурсного забезпечення ЗС України 3 можливостями національної економіки як у мирний час, так і під час збройного протистояння.

Серед факторів, які визначальним чином впливають на визначення напрямів та шляхів будівництва та розвитку Збройних Сил України з метою забезпечення необхідного рівня ВЕБ держави, особливе місце належить економічним факторам. Перехід системи оборонного планування України до планування розвитку $3 \mathrm{C}$ із застосуванням методу "планування на основі спроможностей" передбачає зміну вектору планування від принципу “визначаємо очікуваний результат та потребу для його реалізації по максимуму, а там як дадуть”, до принципів “обґрунтованого визначення та відповідальності за формування кінцевого результату програм та планів розвитку ЗС України", тобто із урахуванням реальних економічних можливостей держави щодо забезпечення створення відповідних спроможностей військ (сил) та їх завчасний ефективний розподіл за напрямами, завданнями та заходами програм та планів розвитку. Сьогодні спрямованість системи оборонного планування України на досягнення необхідних спроможностей військами (силами) в межах існуючих ресурсних обмежень визначає необхідність і актуальність аналізу та оцінювання впливу економічних факторів на процес будівництва та розвитку Збройних Сил. Тобто оцінювання реальних ресурсних (економічних) можливостей держави щодо забезпечення розвитку оборонної ії складової 3 подальшим урахуванням результатів цього оцінювання під час формування програм (планів) розвитку 3 С України стає обов'язковим атрибутом визначення очікуваних кінцевих результатів будь-якого плану та програми розвитку 3 С України, що в свою чергу підкреслює значимість результатів аналізу та оцінювання впливу воєнно-економічних факторів на стан розвитку ЗС України, а й відповідно й рівень ії воєнно-економічної безпеки. 


\section{Постановка завдання}

Метою статті $€$ визначення основних економічних факторів, які визначальним чином впливають на будівництво та розвиток зС України, розкриття ієрархічності їх впливу, а також оцінювання ступеня їх впливу на кінцеві (очікувані) результати виконання програм та планів розвитку ЗС України та достовірність визначення необхідного рівня воєнно-економічної безпеки держави.

\section{Виклад основного матеріалу}

Сьогодні реалістичність очікуваних результатів будь-яких програм або планів розвитку зС України можлива тільки за умови правильного врахування впливу різних факторів, що напряму чи опосередковано будуть впливати на сам процес розвитку. Важливість впливу економічних факторів на різні процеси розвитку систем 3 С зазначається в багатьох джерелах, але практичне формування системності їх впливу на сам процес розвитку 3 С розкрито не повністю.

Аналіз можливих наслідків їх впливу на стан будівництва та розвитку ЗС України проводиться в більшості випадків без системного підходу, тобто на окремих рівнях. Щодо питання впливу на сам процес розвитку, то однозначних поглядів не має зовсім, тому спроба авторів щодо визначення економічних факторів за їх ієрархіями впливу, аналіз можливих змін під час вибору напрямів та шляхів розвитку 3С України на основі врахування змін економічних факторів, спроба оцінювання ступеня їх впливовості на процес розвитку ЗС України підкреслює актуальність досліджуваного питання.

Методологія поняття будівництво Збройних Сил, показує, що цей термін тісно пов'язаний із поняттям воєнного будівництва, але ці системи розташовані на різних рівнях (рис. 1). Будівництво Збройних Сил $\epsilon$ підсистемою воєнного будівництва, але вони тісно взаємозалежні одне від одного. В свою чергу будівництво ЗС поділяється також на підсистеми більш нижчого порядку.

Теж саме відбувається і з факторами, які впливають на обидві ці системи. Вони будуть мати своєрідну ієрархію, верхні будуть впливати на процеси більш нижчого порядку, а також обов'язково поділятися на зовнішні та внутрішні (рис. 2). Але треба відмітити, що фактори більш нижчого порядку не можуть впливати на систему більш вищого порядку, або якщо можливий зворотний зв'язок, то він має дуже низьку степінь впливу.

Серед факторів, які вирішальним чином діють на усі з вище зазначених систем, особливе місце належить економічному фактору, який постійно впливає на рішення будь-яких воєнних завдань та на будь-якому рівні. Розвиток матеріального виробництва, характер взаємовідносин між соціальними групами, їх економічні інтереси в значній мірі впливають на процес будівництва та розвитку 3C, на їх цілі, на їх характер та на кінцевий результат. Тому, вирішення завдання щодо визначення впливу економічних факторів на вибір подальших напрямів та шляхів розвитку ЗС України з метою формування найбільш адекватних економіці України поглядів на розвиток їх 3С на найближчу перспективу $\epsilon$ питанням своєчасним та необхідним. До головних недоліків багатьох планів розвитку сьогодні можна віднести невірне врахування факторів, які впливають на самі процеси, не спроможність визначити меж змін в кінцевому результаті за умов змін деяких факторів, не здатність чутливо реагувати на зміни факторів за плановий період. Документи довгострокового та середньострокового планування сформовані без урахування прогнозованих оцінок змін основних воєнно-економічних факторів будуть не реалістичними та не здатні дати чітку оцінку того, що буде через рік, п'ять або десять років. 


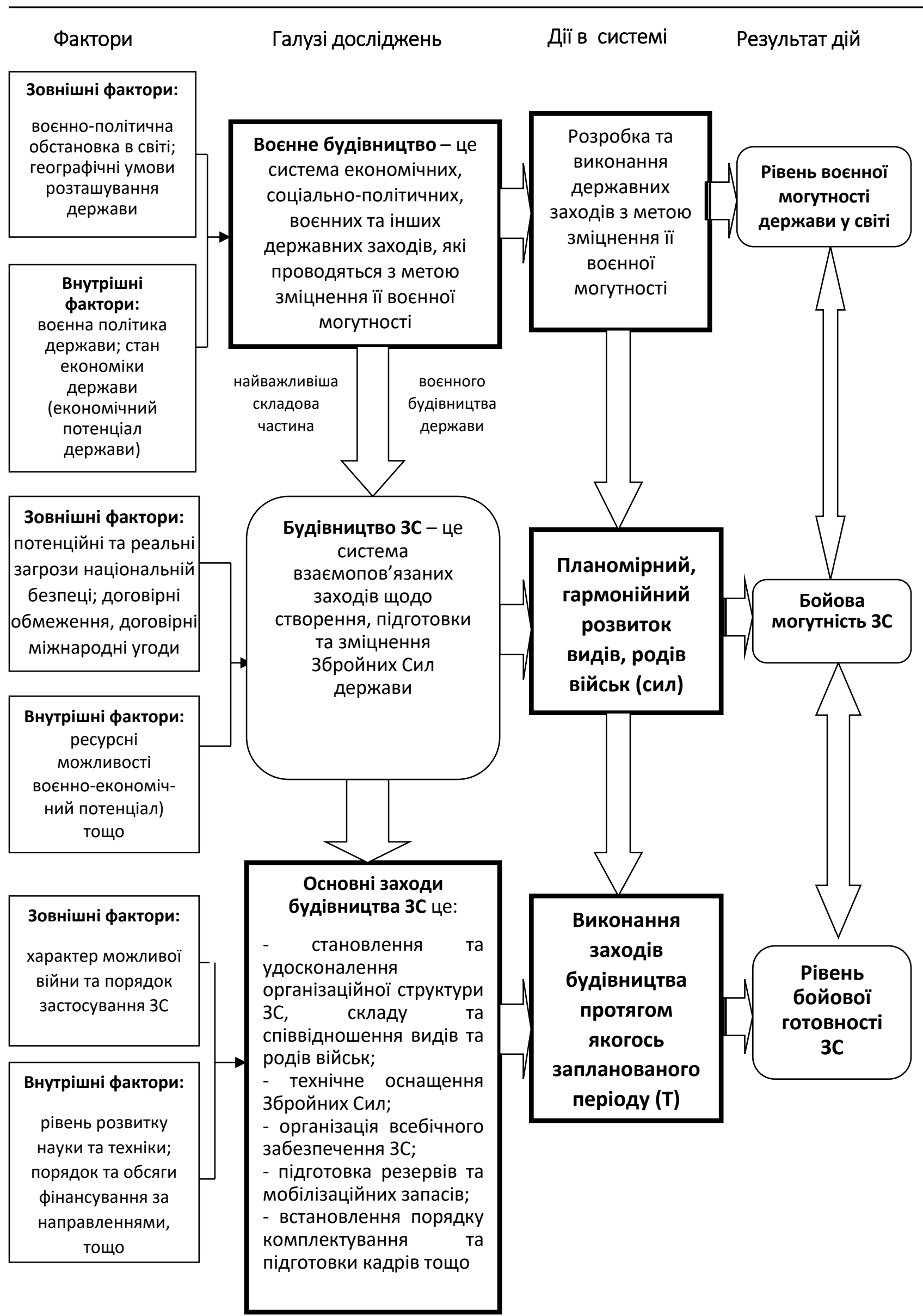

Рисунок 1 - Взаємозв'язок факторів та галузей дослідження 


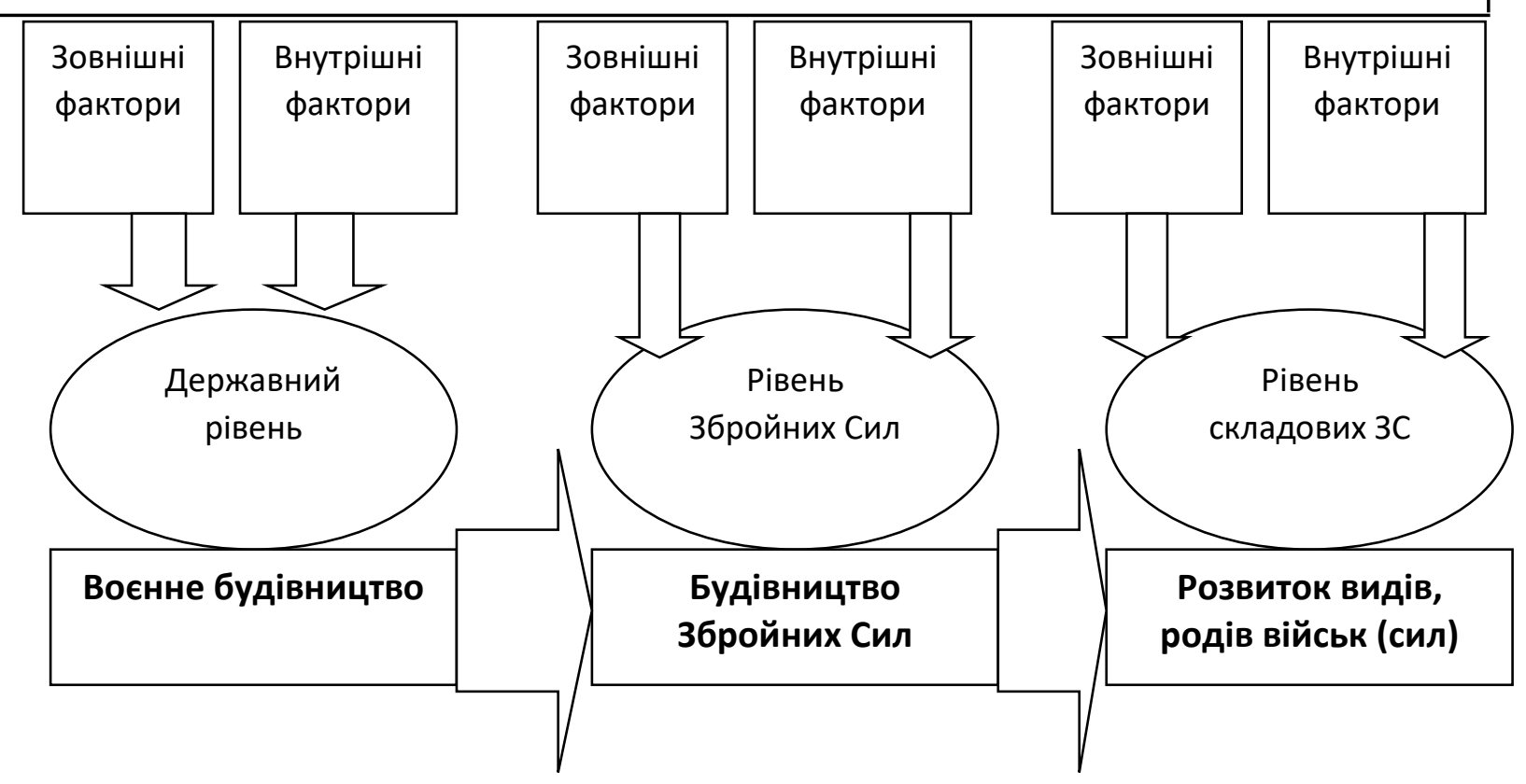

Рисунок 2 - Порядок впливу факторів на відповідні їм системи різного рівня підпорядкованості

До основних причин такого стану можна віднести не достатня увага з боку спеціалістів оборонного планування та управління оборонними ресурсами щодо важливості врахування економічних факторів в процесі планування, недосконалість розуміння ієрархічної їх побудови та взаємозв'язку 3 різними системами ЗС України, відсутність гнучкого підходу до визначення напрямків розвитку та кінцевого результату планування за умови врахування змін впливу факторів в запланований період на процес розвитку тощо.

Оцінювання впливу воєнно-економічних факторів на розвиток ЗС України було проведено експертними методами та методами регресійного та кореляційного аналізу. Отримані результати показують, що воєнні зовнішні фактори - це воєнно-політична обстановка (рівень загроз національній безпеці, ймовірний склад військ противника), становить $35 \%$; нормативно-правові та законодавчі акти, що регламентують розвиток 3С України, - 18\%; вимоги керівництва держави до стану захищеності національних інтересів на середньострокову та довгострокову перспективу - $21 \%$; демографічний стан - $26 \%$.

До воєнних внутрішніх факторів належать вимоги керівництва 3С стосовно готовності до виконання завдань (військових / цивільних, чисельності бойових частин / частин забезпечення), що становить $28 \%$; рівень оснащеності ЗС України озброєнням та військовою технікою (бойовий потенціал) $44 \%$; наявність елементів військової інфраструктури - $11 \%$; рівень підготовки особового складу - $17 \%$.

Оцінювання впливу економічних факторів на розвиток ЗС України показує, що економічні зовнішні фактори, а саме стан розвитку економіки держави - показник валового внутрішнього продукту (ВВП), динаміка його зростання становить $37 \%$; рівень забезпеченості матеріальними ресурсами (промисловість / сільське господарство) відповідає $21 \%$; рівень розвитку оборонно-промислового комплексу - $13 \%$; рівень фінансування потреб 3С України - $29 \%$.

До економічних внутрішніх факторів належить рівень фінансування програм розвитку ЗС України - $51 \%$; рівень забезпеченості військовослужбовців ЗС України - $23 \%$; рівень соціальноекономічного захисту військовослужбовців $19 \%$; рівень стабільності національної валюти (рівень інфляції) - 7 \%. 


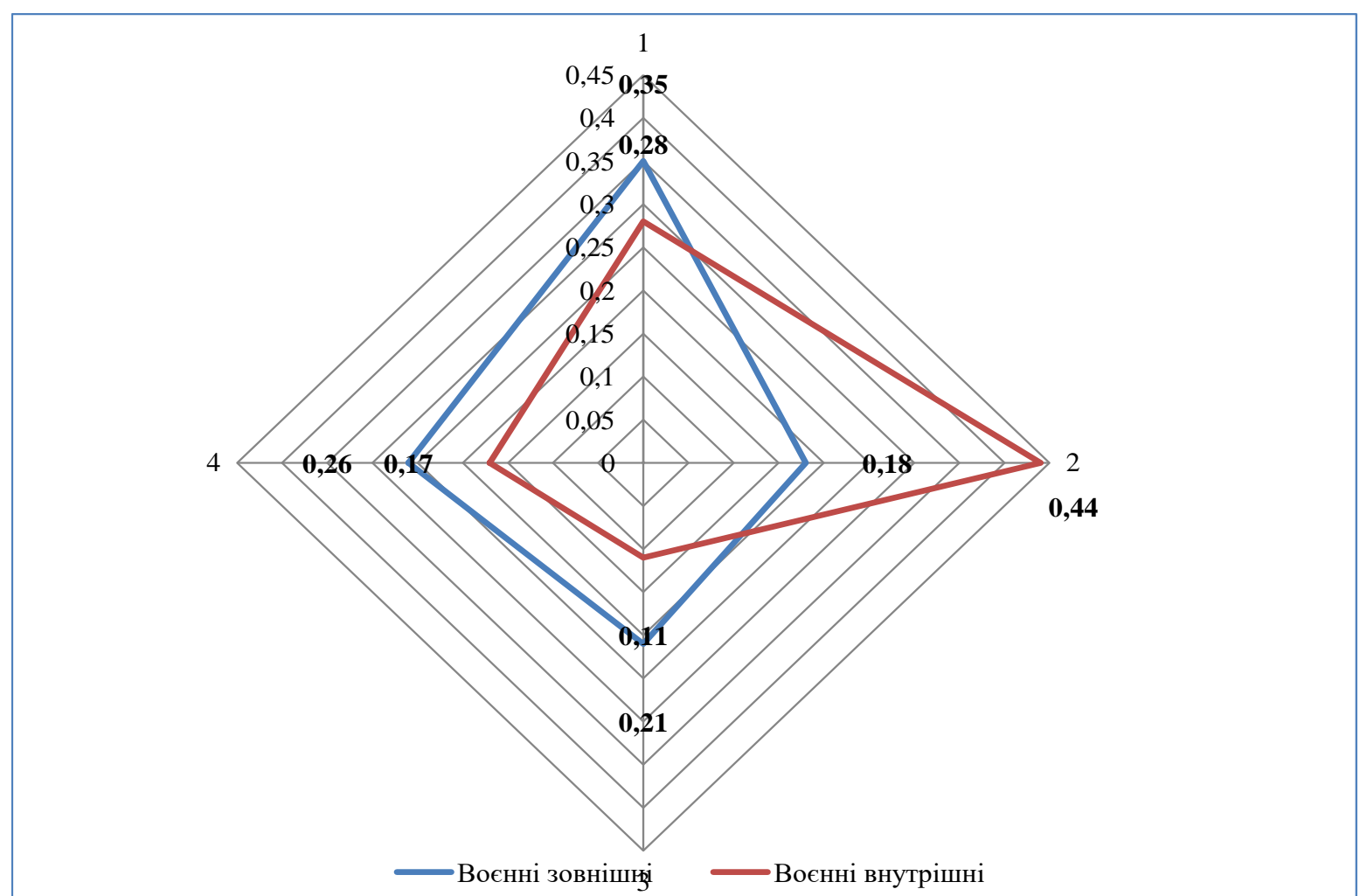

Рисунок 3 - Пелюсткова діаграма оцінювання впливу основних зовнішніх та внутрішніх воєнних факторів на розвиток ЗС України

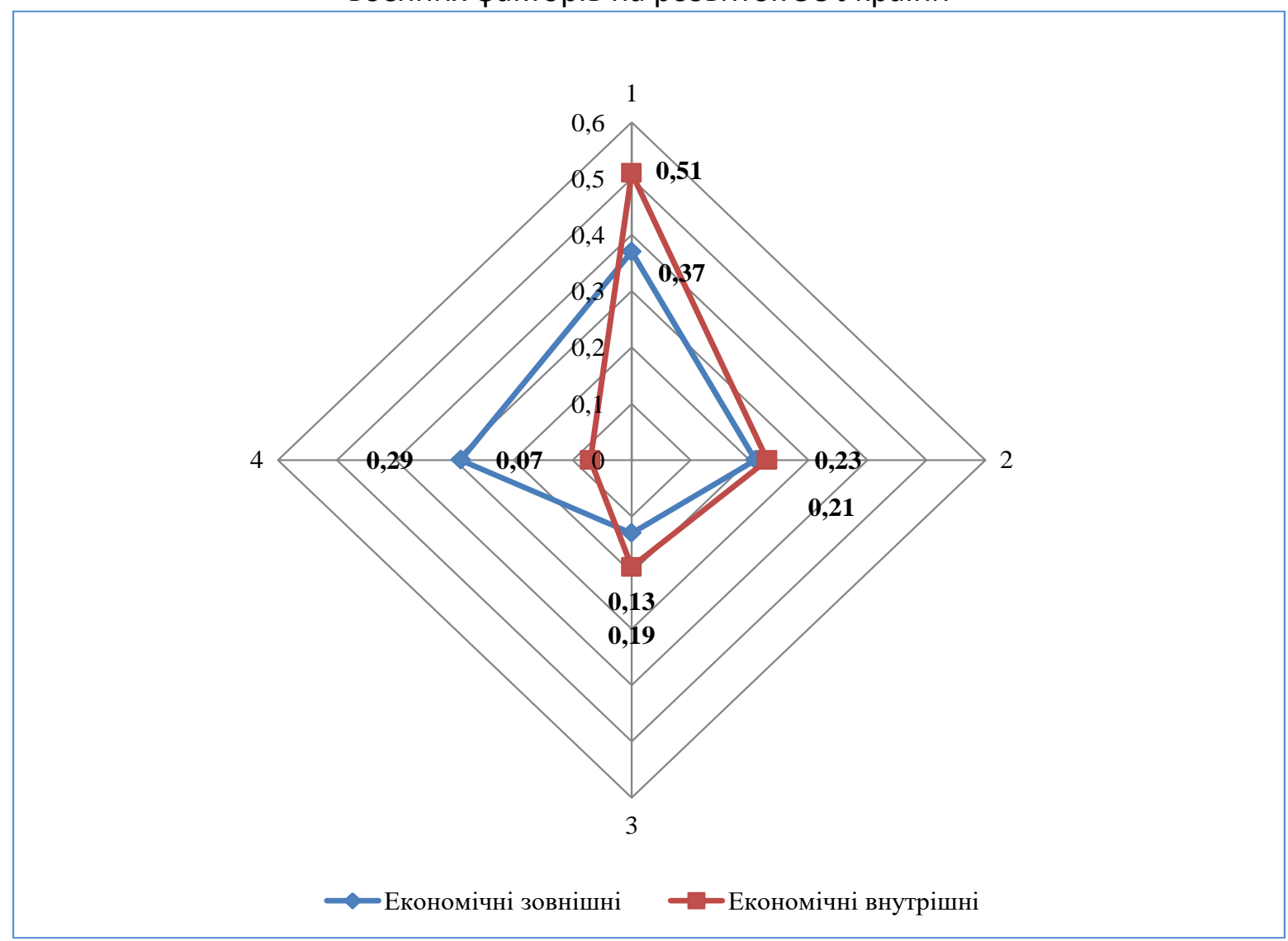

Рисунок 4 - Пелюсткова діаграма оцінювання впливу основних зовнішніх та внутрішніх економічних факторів на розвиток ЗС України 
Аналіз факторів, які впливають на розвиток зС України показав, що: найбільший показник впливу мають фактори: достатності фінансування запланованих заходів будівництва та розвитку ЗС України (понад 26\%); достовірності очікуваних кінцевих результатів програм та планів розвитку 3 С України (понад 21\%); ефективності освоєння виділених державних коштів (понад 17\%); рівень інфляції національної валюти під час безпосереднього виконання програми (понад 11\%). Загальний показник впливу визначених економічних факторів на розвиток 3С України від усієї сукупності факторів складає від 60 до 75\% в період 20002021 років.

Економіка $\epsilon$ матеріальною основою воєнної могутності держави. її можливості та здатності щодо забезпечення суспільних потреб, в тому числі і військових, в матеріальних благах та послугах виражаються через такі категорії, як економічний і воєнноекономічний потенціали. Величини цих потенціалів будуть впливати як на сам процес розвитку ЗС України та держави взагалі так і на кінцевий результат цих процесів, а саме воєнну могутність держави та бойова могутність їі ЗС. Тобто головними економічними факторами, які безпосередньо впливають на процеси розвитку ЗС України та держави можна вважати ії економічний та воєнно-економічний потенціали. Ієрархічна побудова основних економічних факторів, які впливають на процеси розвитку держави, Збройних Сил та їх видів, родів військ (сил) наведена на рис. 3.

Аналізуючи рис. 3 видно, що напрямки розвитку ЗС $\epsilon$ функцією від напрямків розвитку держави та її загальної оборонної направленості, які формуються під впливом наведених на рисунку зовнішніх та внутрішніх факторів.

Тобто можливий рівень бойової могутності зС України $\left(W_{3 c}\right) \in$ функцією від економічних можливостей держави на вищих рівнях (загально-оборонному та державному), які формуються під впливом різноманітних факторів, деякі з яких наведені на рис. 3:

$$
W_{\text {зС }}=f\left(E_{\text {об. }} ; W_{\text {держави }}\right),
$$

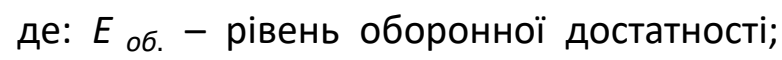
$W$ держави - рівень воєнної могутності держави.

Зрозуміло, що напрямки розвитку на рівні зС України формуються під впливом усієї ієрархії факторів, які впливають на найбільш нижчі напрямки розвитку, що стосується видів, родів військ (сил) та на їх чинники, що ïх формують (рис. 4). Тобто можна сформулювати такий постулат, що фактори більш вищого порядку безпосередньо впливають на фактори нижчого рівня та на сам процес розвитку на відповідному рівні, сформовані вимоги до якого будуть впливати також на фактори більш нижчого рівня та на вимоги до процесу розвитку нижчого рівня. Але відмітимо, що у державі та ЗС, які прагнуть розвитку - оберненого зв'язку не повинно бути, тому що це не буде вже процесом розвитку.

Зазначимо, що більшість внутрішніх економічних факторів, які впливають на процеси розвитку як держави, так і ії ЗС, безпосередньо визначають напрямки розвитку і формують можливі шляхи для досягнення запланованого результату за своєю природою уявляють собою можливості держави, економіки держави, обороннопромислового комплексу, її військових формувань, Збройних Сил щодо досягнення якогось кінцевого результату, який знаходиться в постійному динамічному русі.

Ми розуміємо, що під час аналізування будь-яких варіантів програм розвитку на будь-якому рівні вони повинні оцінюватися 3 точки зору щодо можливості їх втілення в життя, тобто вони повинні бути реалістичні, а не "фантастичні". Їх реалістичність залежить від вірного, адекватного оцінювання впливу факторів на самі процеси розвитку. Ця оцінка визначає показник достовірності очікуваних кінцевих результатів програм розвитку 3 C України. Економічні фактори, які за своєю більшістю формують обмеження, щодо процесу планування подальшого розвитку системи $є$ одними із основних в процесі оборонного планування, не урахування їх 
динаміки протягом планового періоду призводить до значних похибок під час визначення кінцевого результату, або взагалі до його недосяжності. Але не треба забувати, що перспективне планування не володіє пасивним характером. Воно не ставить себе в повну залежність від наявності ресурсів.
Об'єктивні потреби у виконанні постійно зростаючих завдань $€$ стимулюючим фактором для вишукування нових шляхів подальшого руху процесу розвитку, нових технологій, нових матеріальних ресурсів тощо.

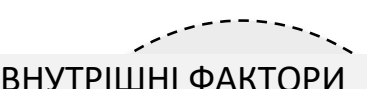

\section{' $\quad$ ' ДЕРЖАВНИЙ РІВЕНЬ}

ЗОВНІШНІ ФАКТОРИ

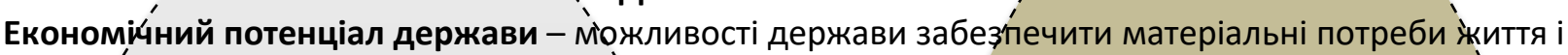
$i^{\prime}$ розвитку суспільства, а так̀ож виробляти все нео,бхідне на випадок війни

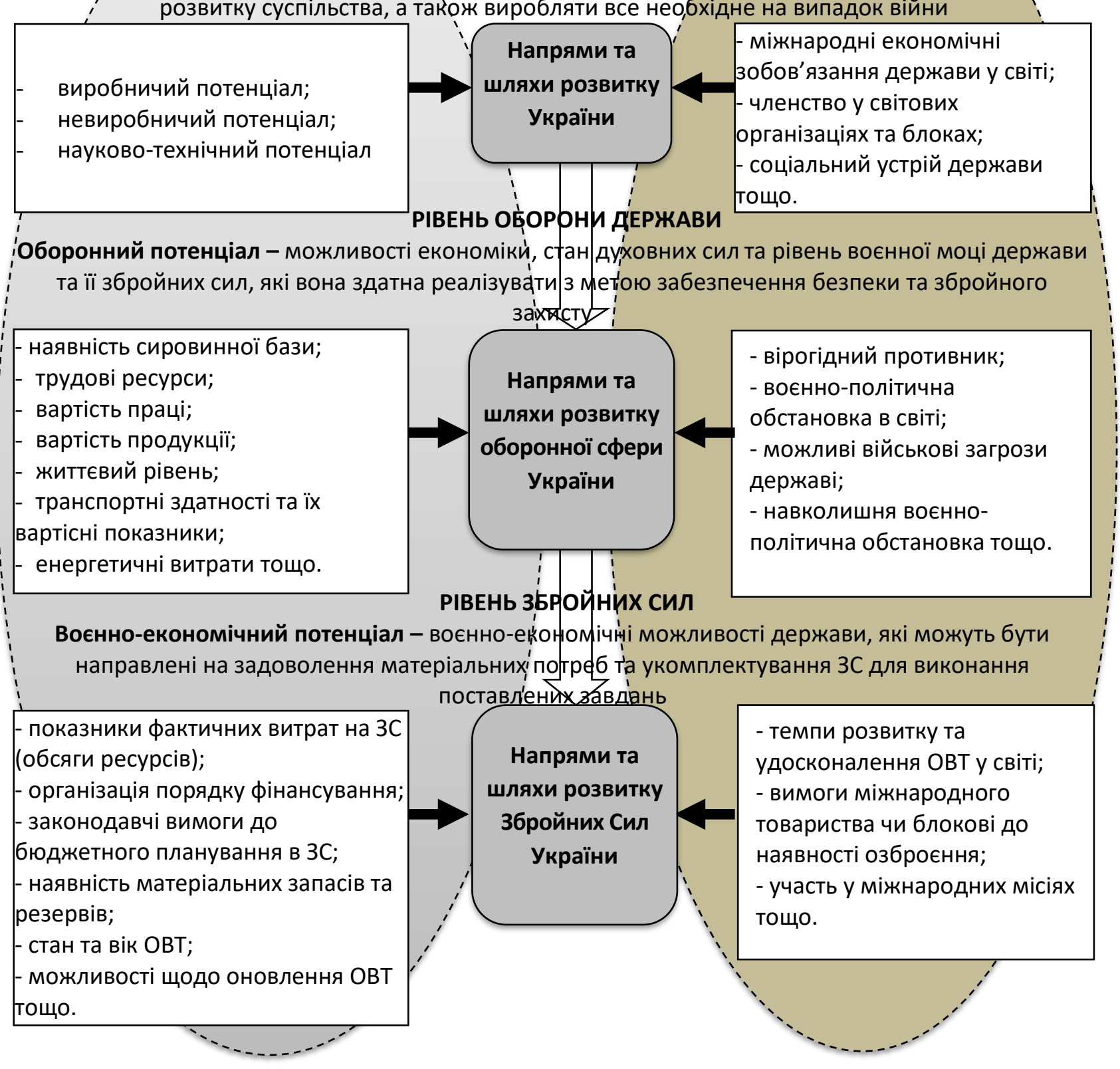

Рисунок 3 - Ієрархія основних економічних факторів, які впливають на процеси розвитку ЗС України

Під час процесу планування розвитку не потрібно забувати про виникнення можливих невизначеностей, які можуть поділятися на дві групи. Перша - це недостатньо 
визначення знань про значення тих факторів, змінити які практично не можливо, друга - це фактори, на які можна здійснити вплив та змінити степінь їх впливу на кінцеві очікувані результати програм розвитку ЗС України.

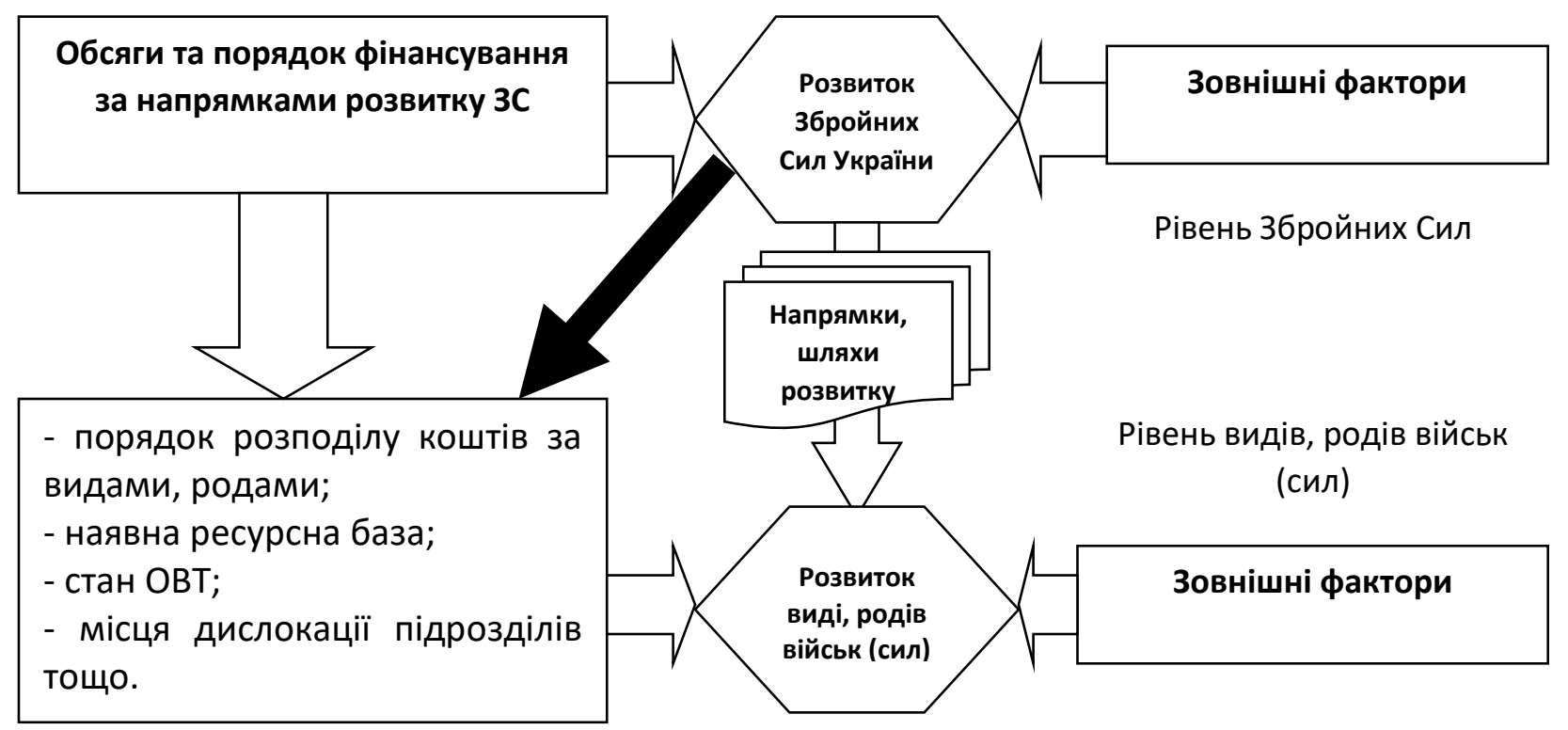

Рисунок 4 - Нижчий рівень економічних чинників, які впливають на процеси розвитку видів, родів військ (сил)

У загальному вигляді залежність процесу розвитку такої системи як ЗС України від впливів на них економічних факторів можна представити як на рис. 5, де вимоги сьогодення формують необхідність гнучкості планування, бо чітко спрогнозувати усіх факторів, що впливають зараз на процеси розвитку 3С України, оборонної сфери держави та України взагалі дуже важко. Сьогодні в процесі оборонного планування обов'язково необхідно визначати межі щодо можливого виконання запланованих завдань та заходів розвитку ЗС України, тобто фактори, які сьогодні постійно змінюються можуть впливати на якісні показники визначених напрямків розвитку усієї системи 3С, а також можуть дозволити під час досягнення результатів за визначеними напрямами змінити шляхи досягнення кінцевої цілі, що надасть можливість досягти більш бажаних кількісних показників кінцевого результату. Але зазначимо, що зміна шляхів досягнення кінцевого результату за умови врахування вже відомих показників впливу економічних факторів не надасть можливості досягти меж діапазону кінцевого результату через одну ступінь, бо існують інші певні обмеження, які впливають на очікуваний кінцевий результат. Тобто зміною шляхів досягнення найбільш кращого кінцевого результату можна досягти тільки нижньої межі діапазону попередньої ступені кінцевого результату, і те тільки за умови якщо вплив економічних факторів на процес розвитку призводить до досягнення кінцевого результату в визначеному діапазоні більше 50\%.

Наприклад, розглянемо завдання оцінки можливостей реалізації програми розвитку 3С на основі врахування економічних факторів. Бойова могутність $3 \mathrm{C}-$ це сукупність матеріальних (економічних) $\left(F_{\text {ек. }}\right)$ та морально-бойових факторів $\left(F_{M Б}\right)$, які визначають здатність ЗС виконувати поставлені завдання $\left(Z_{3 C}\right)$ та їх стан $\left(Z_{3 C}\right)$ :

$W_{\text {зС }}=f\left(\sum_{i=1}^{K} F_{\text {ек. }} ; \sum_{K=1}^{C} F_{\text {МБ }}\right) \Rightarrow f\left(Z_{3 C} ; S_{3 С}\right)$. (2) 


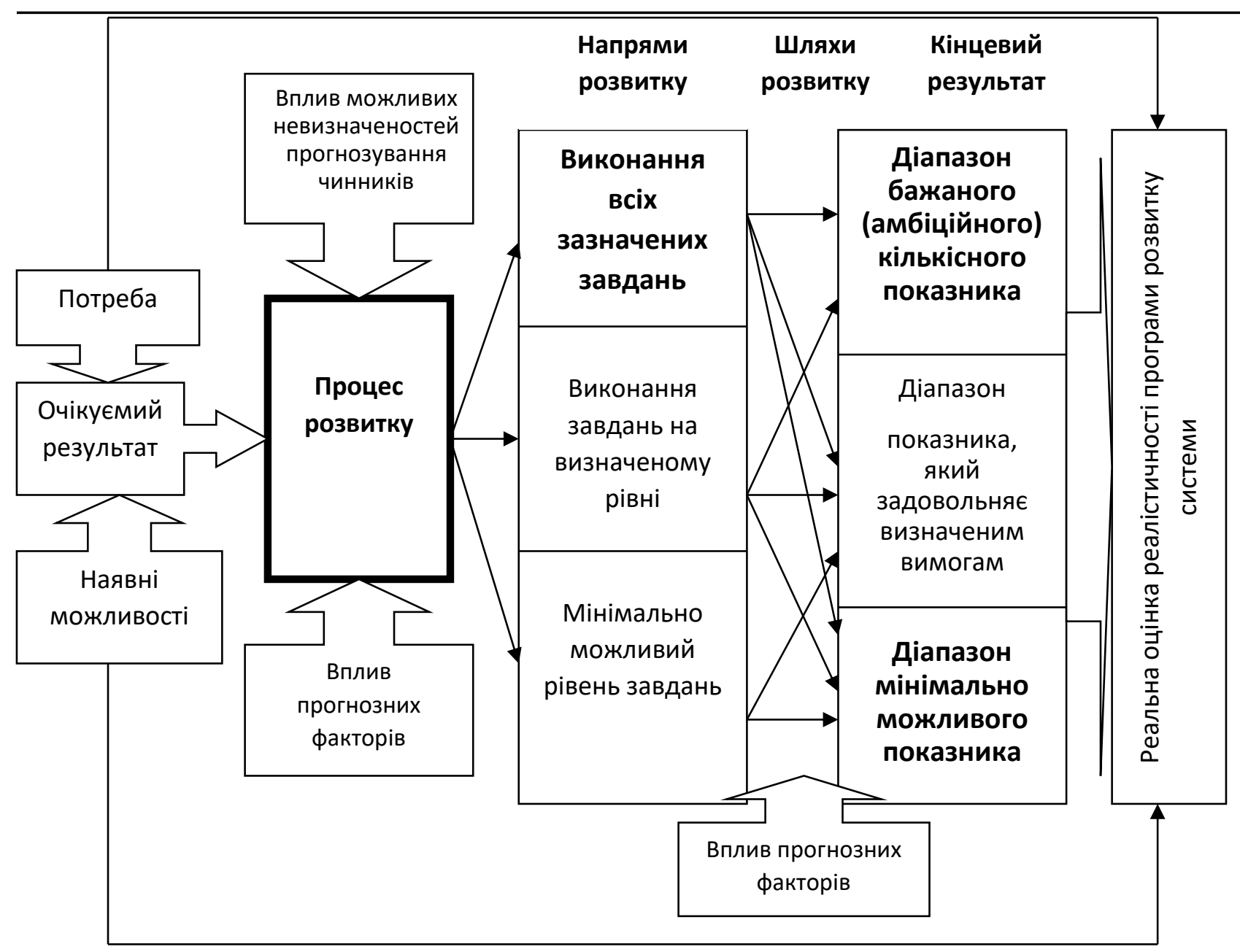

Рисунок 5 - Залежність процесу розвитку 3С від впливу економічних факторів

Тоді завдання оцінювання реалістичності програми розвитку 3 С можна представити як на рис. 6. Припустимо, що за кожним варіантом програми нам відомі практично усі можливі показники економічних факторів, які будуть впливати на процес розвитку (тобто, вартісні показники можливих витрат державою, розподіл ресурсів за роками, обсяги завдань, що будуть покладатися на 3С в цей період $з$ їх вартісними показниками тощо). Відомі також виробничі можливості воєнної промисловості, стан 3С на період складання програми, стан науково-технічного потенціалу 3 тощо. Тоді співставлення обсягів завдань, які повинні виконувати ЗС України в планований період за визначеного рівня їх боєздатності, 3 економічними можливостями держави щодо їх досягнення, які формуються під впливом різних факторів (найголовніші економічні) дає змогу оцінити степінь реалістичності (достовірності) очікуваних кінцевих результатів програми. Але можуть виникати ситуації розмитості визначених кінцевих результатів програмних заходів розвитку ЗС України, наприклад, недостатні промислові потужності будуть вимагати пошуку шляхів їх компенсації за рахунок залучення інших відомств чи створення додаткових промислових потужностей чи залучення інвестицій тощо. Тобто сформований середньостроковий або довгостроковий документ (програма, план) щодо будівництва та розвитку ЗС України та їі оборонної сфери в цілому повинен бути динамічним та здатним адаптуватися до змін обставин, які формуються під впливом тих чи інших факторів. В кінцевому випадку можливий перегляд показників програми вони повинні бути чутливими, але не перевищувати критичні межі. Постійно повинен бути діапазон планування, особливо за показниками середньої або великої 


\begin{tabular}{llllll}
\hline масштабності очікуваних результатів. & корегуватися & на основі фактичних \\
Корегування показників програми може & економічних можливостей держави, що \\
призвести до необхідності перегляду шляхів & обмежуються впливом факторів, але не \\
досягнення кінцевого результатута величини & перевищуючи критичних меж.
\end{tabular}
самого кінцевого результату, який буде

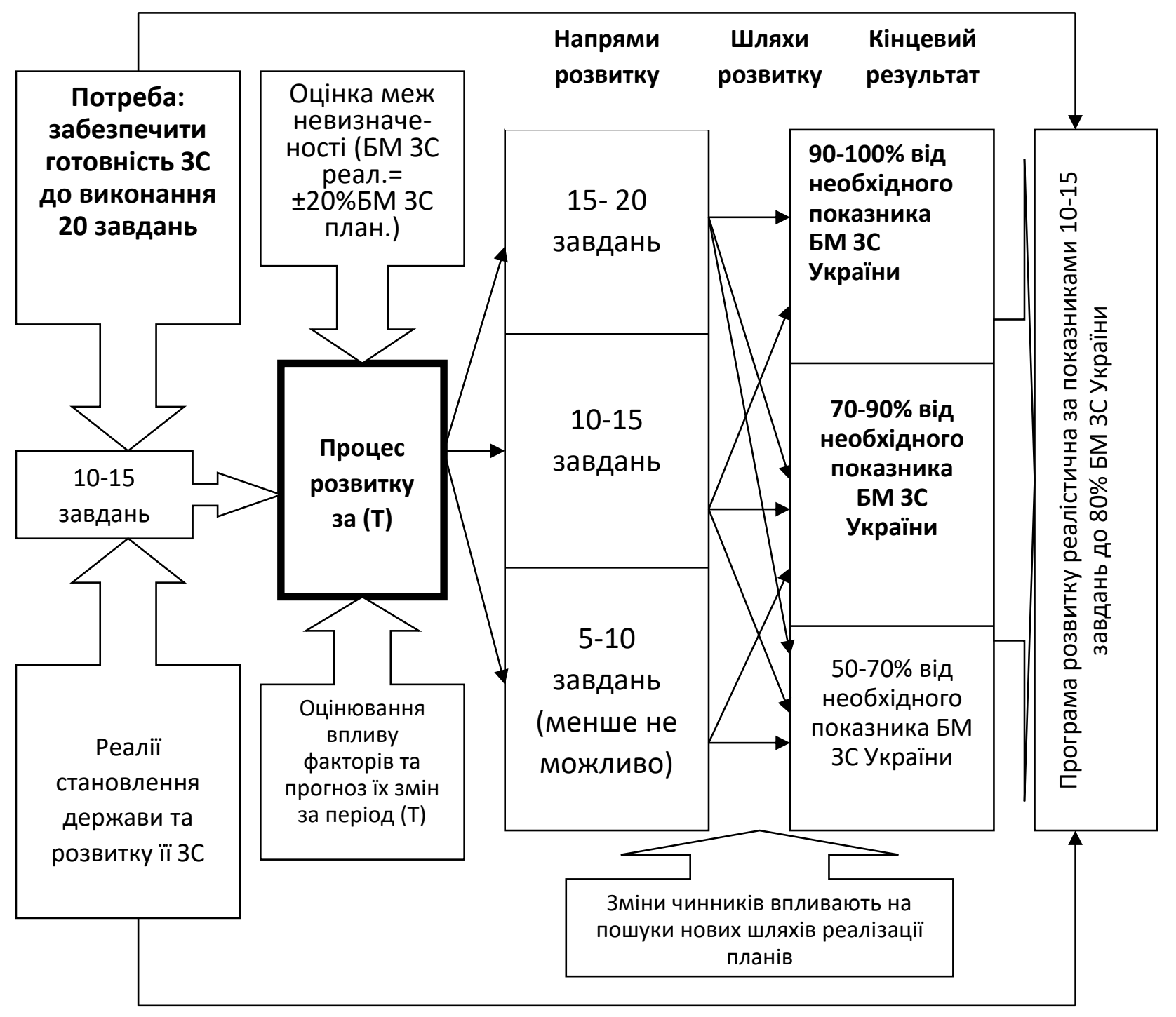

Рисунок 6 - Залежність процесу розвитку 3С від впливу економічних факторів

Завдання формування напрямів розвитку 3С України, визначення можливих шляхів досягнення кінцевого результату, оцінювання показників можливого впливу на ці напрями та шляхи розвитку повинно вирішуватися ітераційно, тобто крок за кроком як в прямій залежності, так і в оберненій цих показників. Тобто здійснюється пошук раціонального (оптимального) рішення в процесах оборонного планування від амбіцій та планування від можливостей (планування від ресурсів).

Розроблення планів та програм, аналіз їх степені реалізації має дуже важливе практичне значення. Цей процес визначає перспективи розвитку будь-якого об'єкту (3С, держава). Крім того, перспективне планування дозволяє на науковій основі визначити шляхи створення та удосконалення різних військових систем під 
час процесу їх розвитку 3 урахуванням впливів усього спектру факторів.

Впливи економічних факторів на вибір напрямів розвитку ЗС України будуть лімітувати кількість амбіційних завдань, що будуть покладатися на 3 са навпаки при їх зростанні в обсягах чи досягнення найбільшої раціональності в діях навпаки додавати найбільш актуальні завдання в перелік завдань, що необхідно виконувати у визначений плановий період їх розвитку. Шляхи вирішення будь-якого завдання 3С також будуть залежати від можливих впливів економічних факторів та будуть відбиватися на кінцевому результаті.

\section{Висновки}

Результати аналізу та оцінювання впливу воєнно-економічних факторів на стан розвитку ЗС України та рівень їі воєнноекономічної безпеки дозволив визначити ієрархічну схему опису взаємозв'язку факторів та галузей дослідження на різних рівнях та описати порядок їх впливу на об'єкти та процеси розвитку відповідних систем за ієрархією, а також визначено можливі впливи на напрями розвитку 3 С України та можливе їх врахування під час вибору шляхів досягнення кінцевого результату на основі процесу оцінювання степені реалізації їх програм розвитку. У статті запропоновано для забезпечення гнучкості процесу оборонного планування розглядати впливи економічних факторів з урахуванням ïх можливих змін і невизначеностей та відповідно до них формувати гнучкі вимоги до можливого кінцевого очікуваного результату, особливо під час середньострокового та довгострокового оборонного планування. Основним напрямом подальших досліджень за визначеною у статті тематикою повинно бути формування системи показників, які характеризують самі економічні фактори та розкривають сутність їх впливу, з подальшим обґрунтуванням їх взаємозв'язку, практичної взаємозалежності з цільовими показниками програм розвитку ЗС України, показниками необхідного рівня воєнно-економічної безпеки країни на визначений період планування, проведення практичного розрахунку достовірності визначених кінцевих результатів будь-якої програми розвитку та ЗС України базуючись на реальних економічних держави щодо їх ресурсного забезпечення.

\section{Список використаних джерел}

1. Семененко О. М., Бойко Р. В., Водчиць О. Г., Добровольський Ю. Б., Бердочник Д. В., Ярошенок А. В. Основні методологічні аспекти воєнно-економічного забезпечення обороноздатності держави: теорія та практика // Системи обробки інформації: щокварт. наук.-тех. журн. Харків: ХНУПС, 2017. № 3 (51). С. 165-175.

2. Масловський С.С., Семененко О.М., Водчиць О.Г., Бойко Р.В., Корочкін О.А., Науменко М.В., Кірвас В.В. Сучасні особливості впровадження методу “планування на основі спроможностей” у систему оборонного планування в Збройних Силах України / Збірник наукових праць Харківського національного університету Повітряних Сил. 2017. № 5(54). С. 187-196.
3. Семененко О.М. Особливості планування розвитку збройних сил на основі можливостей держави за досвідом країн НАТО [Текст] / О.М. Семененко, М.О. Слюсаренко // Зб. наук. пр. ЦНДІ ЗС України. - К., 2012. - № 4 (62). - С. 102-109

4. Воено-энциклопидический словарь / Под ред. Н.В.Огаркова. - М.: Воениздат, - 1984. C. 499

5. Викулов С. Ф. Методология оценки оборонного и военно-экономического потенциалов государства / Центральный экономико-математический институт РА. URL: $\quad$ https://cyberleninka.ru/article/n/ metodologiya-otsenki-oboronnogo-i-voennoekonomicheskogo-potentsialovgosudarstva/viewer (дата звернення: 


\subsubsection{9).}

6. Хрусталёв Е. Ю. Оборонный потенциал России В контексте современной международной конкуренции и глобализации. URL: https://cyberleninka.ru/ article/n/oboronnyy-potentsial-rossii-vkontekste-sovremennoy-mezhdunarodnoykonkurentsii-i-globalizatsii (дата звернення: 22.07.2019).

7. Семененко О. М., Корнийчук С. П., Бокий В. Г., Каблуков О.А. Современные особенности военно-экономического обеспечения и оценки необходимого уровня обороноспособности Украины // SDirect 24 Safety, Society, Science. 2020. № 2 (12). C. 5176. URL: https://www.sdirect24.org/kopianato-deep-no-13

8. Радвик Б. Военное планирование и анализ систем сокр. перевод с англ. В. Базарова, Л. Какунина, К.Трофимова под ред. А. М. Пархоменко. Москва: Воениздат, 1972. $477 \mathrm{c}$.

9. Жуков Г.П., В Викулов С. Ф. Военноэкономический анализ и исследование операций. Москва: Воениздат, 1987. 440 с.

10. Леонтьев В. В. Межотраслевая экономика /В.В.Леонтьев. Москва: ОАО «Издательство «Экономика», 1997. 479 с.

11. Актуальні проблеми реалізації політики національної безпеки України в оборонній сфері. Вип. 27 / За заг. ред. В. П. Горбуліна. К.: ДП „НВЦ “Євроатлантикінформ”, 2006. -
$192 \mathrm{c}$.

12. Проскурин С. А. Обороноспособность В системе национальной безопасности страны // Военная мысль. - 1992. - № 1. - С. $59-61.13$.

13. Смолянюк В. Ф. Військова могутність України: Теоретико-методологічні засади формування та розвитку (політологічний аналіз досвіду 1990-х років): [Монографія]. Київ; Ірпінь: ВТФ „Перун", 2000. - 448 с.

14. Табунов Н. Д. Оборонная мощь страны: сущность и структура // Коммунист Вооруженных Сил. 1982. № 7. С. $18-25$.

15. Шахов А. Н. Политический потенциал оборонной мощи государства. - М.: ГА ВС, 1992. - $148 \mathrm{c}$.

16. Военная экономика. Теория и актуальные проблемы / [Олейник Г.С., Пожаров А.И., Ткачев В.Н. и др.]; под редакцией А. И. Пожарова. - М.: Военное издательство, 1999. $-410 \mathrm{c}$.

17. Воєнна економіка: / [Ворона О.І., Дубровіна О.О., Онофрійчук П.В. та ін.]; под ред. В.М. Шемаєва. - К.: НАОУ, 2008. - 328 с.

18. СІПРІ 2019: Щорічник: Озброєння, роззброєння та міжнародна безпека: Пер. 3 англ./Стокгольм. міжнар. ін-т дослідження миру; Укр. центр екон. і політ. досліджень ім. О.Разумкова; Редкол. укр. вид.: О. Мельник (керівник проекту) та ін. - К.: Заповіт, 2021. 662c. ISBN 978-966-7272-98-2

\section{Анализ и оценка влияния военно-экономических факторов на состояние развития Вооруженных сил Украины и уровень ее военно-экономической безопасности}

\footnotetext{
Олег Семененко* 1 А; Игорь Воронченко 2 в; Игорь Москаленко 3 с; Сергей Пономаренко ${ }^{4}$; ; Сергей Саенко ${ }^{5}$; ; Ирина Борисенко 6 А

* Corresponding author: ${ }^{1}$ д.в.н., профессор, начальник отдела, e-mail: aosemenenko@ukr.net, ORCID: 0000-0001-6477-3414 ${ }^{2}$ Главный инспектор, e-mail: aosemenenko@ukr.net, ORCID: 000-0001-6074-2995

з Соискатель научной степени, e-mail: aosemenenko@ukr.net, ORCID: 0000-0002-7822-6419

${ }^{4}$ Соискатель научной степени, e-mail: aosemenenko@ukr.net, ORCID: 0000-0002-8939-3415

${ }^{5}$ Соискатель научной степени, e-mail: aosemenenko@ukr.net, ORCID: 0000-0002-6713-1545 ${ }^{6}$ e-mail: aosemenenko@ukr.net, ORCID: 0000-0003-1640-853X

А Центральный научно-исследовательский институт Вооруженных Сил Украины, пр-кт Воздухофлотский 28 г. Киев, 03049, Украина

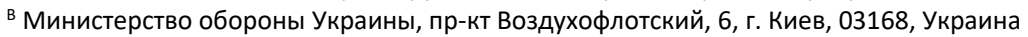

с Национальный университет обороны Украины имени Ивана Черняховского, пр-кт Воздухофлотский, 28, г. Киев, 03049, Украина
} 


\begin{abstract}
Аннотация
Получить наиболее достоверный конечный результат относительно будущего очертания Вооруженных Сил Украины во время оборонного планирования возможно только при условии полного учета влияния различных факторов на сами вооруженные силы, как на отдельную систему государственного уровня, так и на процесс их строительства и развития за определенный планируемый период. В статье авторами раскрыта сущность внешних и внутренних экономических факторов, непосредственно влияющих на состояние строительства и развития Вооруженных Сил Украины и уровень ее военно-экономической безопасности. В статье методом экспертного опроса по имеющейся статистической информации проведена оценка уровня влияния основных военно-экономических факторов на развитие Вооруженных Сил Украины. Авторами также определен порядок взаимосвязи между экономическими факторами и их возможным влиянием на пути и направления развития Вооруженных Сил Украины по разным уровням иерархии процесса оборонного планирования. В статье предложено для обеспечения гибкости процесса оборонного планирования рассматривать влияние экономических факторов с учетом возможных изменений и неопределенностей и в соответствии с ними формировать гибкие требования к возможному конечному ожидаемому результату особенно во время среднесрочного и долгосрочного оборонного планирования.
\end{abstract}

Ключевые слова: безопасность, ресурсы, экономика, анализ.

\title{
Analysis and assessment the influence of military and economic factors on the state of development armed forces of Ukraine and the level of military and economic security
}

\author{
Oleh Semenenko * 1 A; Ihor Voronchenko ${ }^{2}$ A; Ihor Moskalenko ${ }^{3 \text { B; }}$ \\ Serhii Ponomarenko ${ }^{4}$; ; Serhii Saienko ${ }^{5}$; ;ryna Borysenko ${ }^{6 D}$ \\ *Corresponding author: ${ }^{1}$ Dr of military sciences, Prof., Head of Department, e-mail: aosemenenko@ukr.net, ORCID: 0000-0001-6477-3414 \\ ${ }^{2}$ Chief Inspector, e-mail: aosemenenko@ukr.net, ORCID: 000-0001-6074-2995 \\ ${ }^{3}$ Ph.D. student, e-mail: aosemenenko@ukr.net, ORCID: 0000-0002-7822-6419 \\ ${ }^{4}$ Ph.D. student, e-mail: aosemenenko@ukr.net, ORCID: 0000-0002-8939-3415 \\ ${ }^{5}$ Ph.D. student, e-mail: aosemenenko@ukr.net, ORCID: 0000-0002-6713-1545 \\ ${ }^{6}$ e-mail: aosemenenko@ukr.net, ORCID: 0000-0003-1640-853X \\ ${ }^{A}$ Central Research Institute of the Armed Forces of Ukraine, 28, Povitroflotsky, ave, Kyiv, 03049, Ukraine

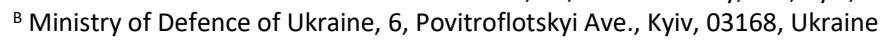 \\ c National Defence University of Ukraine named after Ivan Cherniachovskyi, 28, Povitroflotsky, ave, Kyiv, 03049, Ukraine
}

\begin{abstract}
To obtain the most reliable final result on the future shape of the Armed Forces of Ukraine during defense planning is possible only if full consideration of the impact of various factors on the Armed Forces, both on a separate state level system and on the process of their construction and development. The authors reveal the essence of external and internal economic factors that directly affect the state of construction and development of the Armed Forces of Ukraine and the level of its military and economic security. The article uses the method of expert survey on the basis of available statistical information to assess the level of influence of major military and economic factors on the development of the Armed Forces of Ukraine. The authors also determine the order of the relationship between economic factors and their possible impact on the ways and directions of development of the Armed Forces of Ukraine at different levels of the hierarchy of the defense planning process. In order to ensure the flexibility of the defense planning process, the article proposes to consider the effects of economic factors, taking into account their possible changes and uncertainties, and to form flexible requirements for the possible end result, especially during medium and long-term defense planning.
\end{abstract}

Keywords: security, resources, economy, analysis. 


\section{References}

1. Semenenko, O.M., Boyko, R.V., Vodchyts, O.G., Dobrovolsky, Yu. B., Berdochnyk, D.V., Yaroshenok, A.V. (2017). Basic methodological aspects of military and economic support of the state's defense capabilities: theory and practice. Information processing systems: quarterly. scientific and technical magazine Kharkiv: KhNUPS, № 3 (51). Pp. 165-175.

2. Maslovsky, S.S., Semenenko, O.M., Vodchyts, O.G., Boyko, R.V., Korochkin, O.A., Naumenko, M.V., Kirvas, V.V. (2017). Modern features of the introduction of the method of "capabilitybased planning" in the system of defense planning in the Armed Forces of Ukraine. Proceedings of the Kharkiv National University of the Air Force. № 5 (54). Pp. 187-196.

3. Semenenko, O.M., Slyusarenko, M. O. (2012). Peculiarities of planning the development of armed forces on the basis of state capabilities based on the experience of NATO countries. Coll. Science. etc. CNDI of the Armed Forces of Ukraine. № 4 (62). P. 102-109.

4. Military encyclopedic dictionary. Moscow: Voenizdat, 1984. P. 499.

5. Vikulov, S.F. Methodology for assessing the defense and military-economic potentials of the state / Central Economic and Mathematical Institute of Russian Academy. Available from: https://cyberleninka.ru/article/n/metodologiy a-otsenki-oboronnogo-i-voenno-

ekonomicheskogo-potentsialov-gosudarstva / viewer (access date: 22.05.2019).

6. Khrustalev, E. Yu. Russia's defense potential in the context of modern international competition and globalization. Available from : https://cyberleninka.ru/article/n/oboronnyypotentsial-rossii-v-kontekste-sovremennoymezhdunarodnoy-konkurtsii-i-globalizatsii (access date: 22.07.2019).

7. Semenenko, O.M., Korniychuk, S.P., Bokiy, V.G., Kablukov, O.A. (2020). Modern features of military-economic support and assessment of the necessary level of defense capability of Ukraine // SDirect 24-Safety, Society, Science. № 2 (12). Pp. 51-76. Available from: https://www.sdirect24.org/kopia-nato-deep- no-13

8. Radvik, B. Military planning and analysis of systems abbr. translation from English V. Bazarova, L. Kakunina, K. Trofimova, ed. AM Parkhomenko. Moscow: Voenizdat, 1972. $477 \mathrm{p}$.

9. Zhukov, G.P., Vikulov, S.F. Military-economic analysis and operations research. Moscow: Voenizdat, 1987. 440 p.

10. Leontiev, V.V. Intersectoral economy. Moscow: OJSC Ekonomika Publishing House, 1997. $479 \mathrm{p}$.

11. Current issues of implementation of Ukraine's national security policy in the defense sphere. Vip. 27 / For the head. ed. VP Gorbulin. Kyiv: Euroatlanticinform, 2006. 192 p.

12. Proskurin, S.A. (1992). Defense capability in the national security system of the country. Military Thought. № 1. P. 59-61.

13. Smolyanyuk, V.F. Military power of Ukraine: Theoretical and methodological principles of formation and development (political analysis of the experience of the 1990s): [Monograph]. Kyiv; Irpen: VTF "Perun”, 2000. 448 p.

14. Tabunov, N.D. (1982). Defense power of the country: the essence and structure. Communist of the Armed Forces. № 7. S. 18- 25.

15. Shakhov, A.N. Political potential of the defense power of the state. Moscow: GA MF, 1992. $148 \mathrm{p}$.

16. Military economics. Theory and current issues / [Oleynik, G.S., Pozharov, A.I., Tkachev, V.N. etc.]; edited by A.I. Pozharov. Moscow: Military Publishing House, 1999. 410 p.

17. Military economy: / [Vorona, O.I., Dubrovina, O.O., Onofriychuk, P.V. etc.]; under ed. V.M. Shemaeva. Kyiv: HAOY, 2008. 328 p.

18. SIPRI 2019: Yearbook: Arms, Disarmament and International Security: Per. from English / Stockholm. international Institute for Peace Studies; Ukr. center of econ. and flight. research them. О.Разумкова; Redcol. ukr. ed .: O. Melnyk (project manager) and others. Kyiv: Testament, 2021. 662 p. ISBN 978-966-727298-2 